\title{
Discovery of a Novel Selective Dual Peroxisome Proliferator- Activated Receptor $\alpha / \delta$ Agonist for the Treatment of Primary Biliary Cirrhosis
}

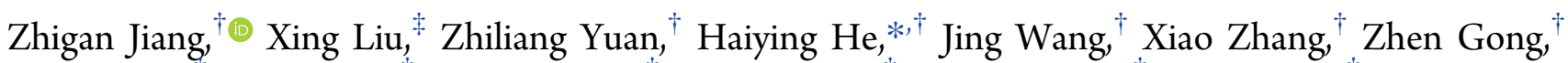
Lijuan Hou, ${ }^{\dagger}$ Liang Shen, ${ }^{\dagger}$ Fengxun Guo, ${ }^{\dagger}$ Jiliang Zhang, ${ }^{\dagger}$ Jianhua Wang, ${ }^{\dagger}$ Deming Xu, ${ }^{\dagger}$ Zhuowei Liu, ${ }^{\ddagger}, \S$ Haijun Li, ${ }^{\ddagger, \S}$ Xiaoxin Chen, ${ }^{*},{ }^{\ddagger}$, Chaofeng Long, ${ }^{\ddagger}$, Jian Li, $^{\dagger}$ and Shuhui Chen ${ }^{\dagger}$

${ }^{\dagger}$ WuXi AppTec (Shanghai) Co., Ltd, 288 FuTe Zhong Road, Shanghai 200131, P. R. China

${ }^{\ddagger}$ R\&D Center, Guangdong Zhongsheng Pharmaceutical Co., Ltd. The Information Area of Xihu Industrial Base, Shilong Town, Dongguan, Guangdong Province 523325, P. R. China

${ }^{\S}$ Guangdong Raynovent Biotech Co., Ltd., Room 1701-1705, Main Building of Rongyi Tower, No. 5, Xinxi Road, SongShan Lake Hi-tech Industrial Development Zone, Dongguan, Guangdong Province 523808, P. R. China

Supporting Information

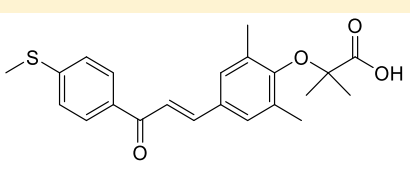

GFT505 (Elafibranor)

$\mathrm{PPAR} \alpha / \delta / \gamma \mathrm{EC}_{50}=225 \mathrm{nM} / 115 \mathrm{nM} / 2116 \mathrm{nM}$

Selectivities against PPAR $\gamma\left(E_{50}\right.$ ratio $): \gamma / \alpha=9, \gamma / \delta=18$

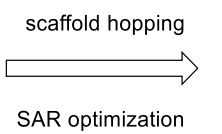

SAR optimization

Compound 5c

$\mathrm{PPAR} \alpha / \delta / \gamma \mathrm{EC}_{50}=8 \mathrm{nM} / 5 \mathrm{nM} / 2939 \mathrm{nM}$

Selectivities against PPAR $\gamma\left(E_{50}\right.$ ratio): $\gamma / \alpha=367, \gamma / \delta=588$

$\% \mathrm{~F}=59.8 \%$ in mouse, $53.3 \%$ in rat

Excellent in vivo efficacy in rat PBC model at $3 \mathrm{mg} / \mathrm{kg} / \mathrm{day}$

ABSTRACT: A novel peroxisome proliferator-activated receptor (PPAR) $\alpha / \delta$ dual agonist $\mathbf{5 c}$ was developed with an $\mathrm{EC}_{50}$ of 8 $\mathrm{nM}$ for $\operatorname{PPAR} \alpha, 5 \mathrm{nM}$ for $\operatorname{PPAR} \delta$, and $>300$-fold selectivity against $\operatorname{PPAR} \gamma\left(\mathrm{EC}_{50}=2939 \mathrm{nM}\right)$, respectively. Further ADME and pharmacokinetic studies indicated 5c possessed distinguished in vitro and in vivo profiles. The excellent in vivo efficacy of compound 5c was demonstrated by the rat primary biliary cirrhosis (PBC) model.

KEYWORDS: Peroxisome proliferator-activated receptor (PPAR), dual agonist, primary biliary cirrhosis (PBC)

$\mathrm{P}$ rimary biliary cirrhosis (PBC), known as a cholestatic liver disease, was caused by an impairment of bile production

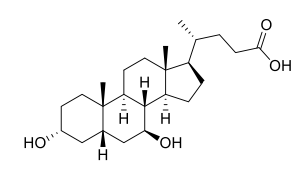

UDCA (ursodeoxycholic acid)

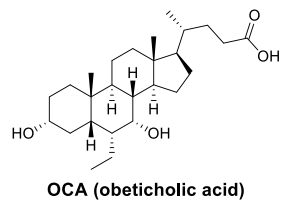

Figure 1. Ursodeoxycholic acid (UDCA) and obeticholic acid (OCA).

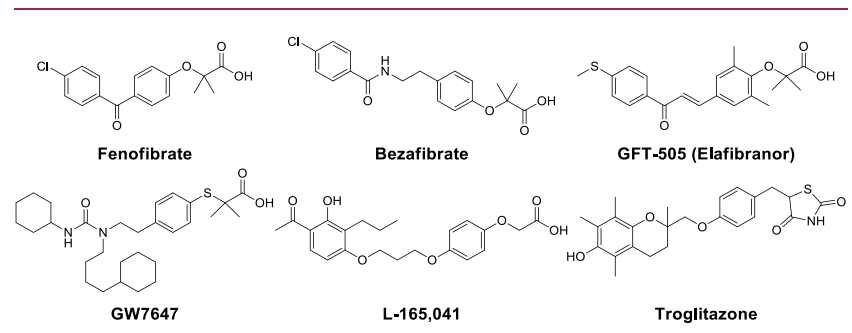

Figure 2. Selected synthetic PPARs agonists.

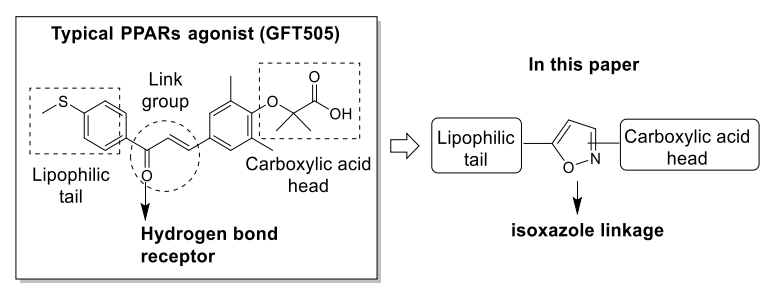

Figure 3. Selected synthetic PPARs agonists.

and characterized by portal inflammation and slow progressive destruction of interlobular bile ducts. ${ }^{1}$ If left untreated, PBC leads to further hepatic damage, such as fibrosis, cirrhosis, liver failure, and hepatocellular carcinoma (HCC), which ultimately results in the requirement of liver transplantation. ${ }^{2}$ To date, the therapeutic options approved by FDA for $\mathrm{PBC}$ patients are ursodeoxycholic acid (UDCA) $)^{3-7}$ and obeticholic acid (OCA)

Received: April 24, 2019

Accepted: June 24, 2019

Published: June 24, 2019 
Scheme 1. General Procedure for the Synthesis of Compounds 5a-5d

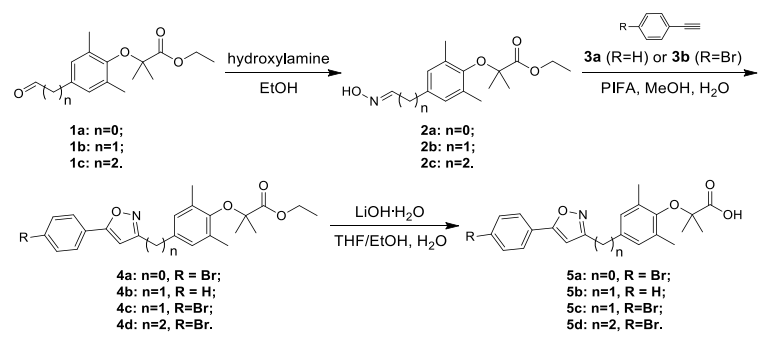

Scheme 2. Synthesis of Compound 10

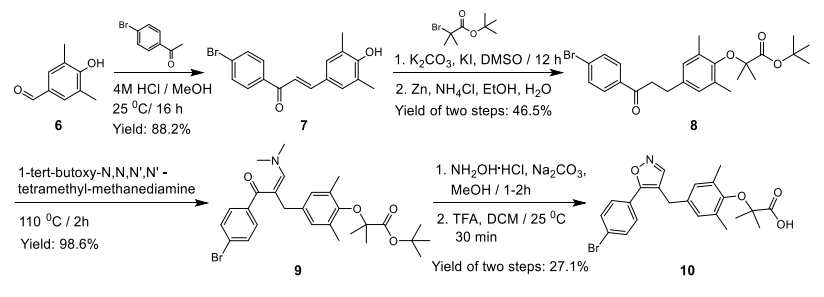

Scheme 3. Synthesis of Compound 17a and $17 \mathrm{~b}$

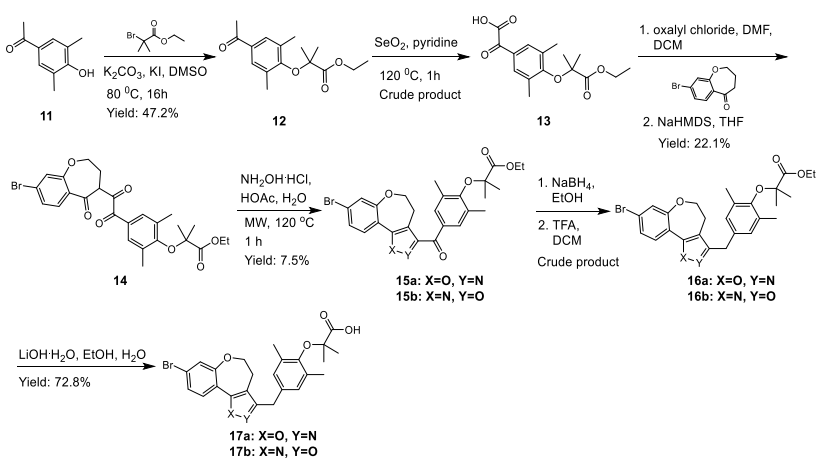

(Figure 1)..$^{8-11}$ These treatments have been demonstrated to delay the progression of $\mathrm{PBC}$; however, up to $40 \%$ of patients have an incomplete response to UDCA monotherapy. ${ }^{12}$ Higher dosage of OCA was found to be related with the pruritus. A recent safety alert warning from FDA indicates that the excessive dosing of OCA may be associated with increased risks of liver injury and death. ${ }^{13}$ These considerations emphasize the unmet medical need for this indication.

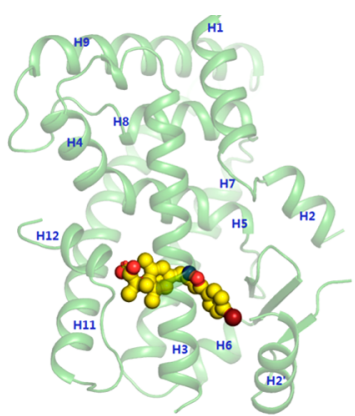

(a)

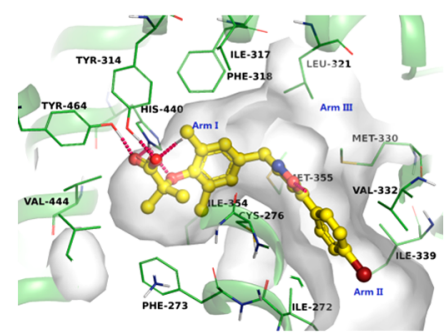

(b)

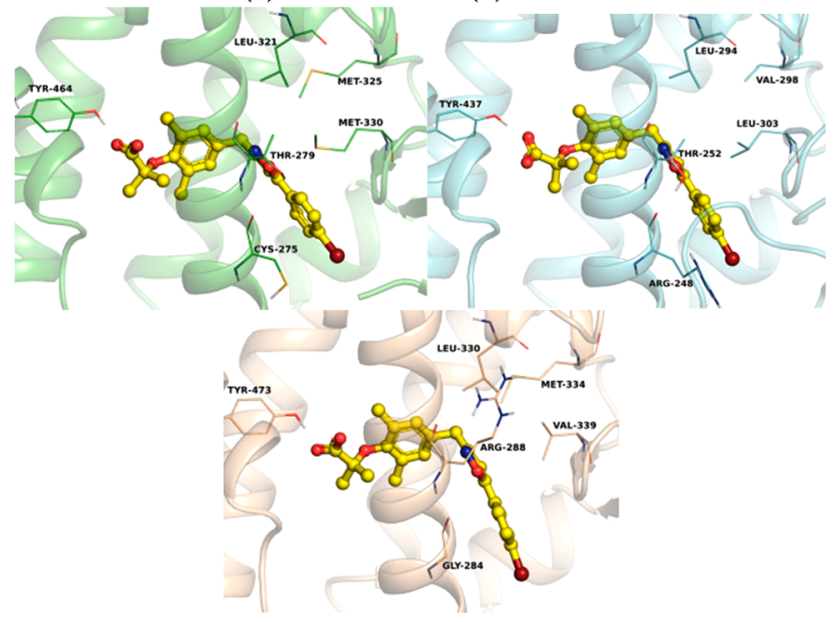

(d)

(e)
Figure 4. Predicted binding modes of $\mathbf{5 c}$ in LBD of the three PPAR isoforms. (a,b) Compound 5c (green) in the three subtypes of PPAR receptor. (c-e) Different residues in the binding pocket of PPAR $\alpha$ (green), $\operatorname{PPAR} \delta$ (blue, ) and PPAR $\gamma$ (yellow). The protein backbone is shown in cartoon, residues are in stick, and ligands are in stick-andball. The figures were generated by Pymol package (The PyMOL Molecular Graphics System, Version 1.8 Schrödinger, LLC)

As effective targets for the therapy of cholestatic diseases, nuclear receptors are critically involved in the regulation of hepatic transporters which regulate a series of bile formation and secretion. ${ }^{14}$ One of these nuclear receptors is peroxisome proliferator-activated receptors (PPARs). Three subtypes of PPARs, namely, $\operatorname{PPAR} \alpha, \operatorname{PPAR} \delta$, and $\operatorname{PPAR} \gamma$, have been known as modulators of many genes implicated in metabolic

Table 1. Evalutation of in Vitro Activities and Selectivities of PPAR $\alpha / \delta$ Dual Agonists

\begin{tabular}{|c|c|c|c|c|c|c|}
\hline \multirow[b]{2}{*}{ entry } & \multirow[b]{2}{*}{ compound } & \multicolumn{3}{|c|}{$\mathrm{EC}_{50}(\mathrm{nM})^{a}$} & \multirow[b]{2}{*}{$\gamma / \alpha\left(\mathrm{EC}_{50}\right.$ ratio $)$} & \multirow[b]{2}{*}{$\gamma / \delta\left(\mathrm{EC}_{50}\right.$ ratio $)$} \\
\hline & & $\operatorname{PPAR} \alpha(\% \text { activation })^{b}$ & $\operatorname{PPAR} \delta$ (\% activation) ${ }^{b}$ & $\operatorname{PPAR} \gamma(\% \text { activation })^{b}$ & & \\
\hline 1 & GW7647 & $5(100 \%)$ & $\mathrm{ND}^{c}$ & $\mathrm{ND}$ & / & / \\
\hline 2 & L-165,041 & ND & $61(100 \%)$ & ND & l & / \\
\hline 3 & Troglitazone & ND & ND & $215(100 \%)$ & / & / \\
\hline 4 & GFT505 & $225(117 \%)$ & $115(72 \%)$ & $2116(93 \%)$ & 9 & 18 \\
\hline 5 & $5 a$ & $>10,000(5 \%)$ & $\mathrm{ND}$ & ND & / & / \\
\hline 6 & $5 c$ & $8(92 \%)$ & $5(79 \%)$ & $2939(110 \%)$ & 367 & 588 \\
\hline 7 & $5 \mathbf{b}$ & $385(85 \%)$ & ND & $\mathrm{ND}$ & / & / \\
\hline 8 & 10 & $2821(78 \%)$ & $\mathrm{ND}$ & $\mathrm{ND}$ & / & / \\
\hline 9 & $5 d$ & $27(134 \%)$ & $5(73 \%)$ & $457(78 \%)$ & 17 & 91 \\
\hline 10 & $17 a$ & $8974(50 \%)$ & $\mathrm{ND}$ & $\mathrm{ND}$ & / & / \\
\hline 11 & $17 \mathrm{~b}$ & $3423(85 \%)$ & ND & ND & / & / \\
\hline
\end{tabular}

${ }^{a}$ Data generated using nuclear hormone receptor (NHR) assay. ${ }^{b}$ For PPAR $\alpha, \delta$, and $\gamma \%$ activation, data were generated comparing with GW7647, L-165,041, and troglitazone, respectively. ${ }^{c} \mathrm{ND}$ : no data. 
Table 2. ADME Profile of Compound 5c

\begin{tabular}{lc}
\multicolumn{1}{c}{ study } & result \\
$\mathrm{Cl}$ of microsomal (human/rat) $\mathrm{mL} / \mathrm{min} / \mathrm{kg}$ & $<9.6 /<9.6$ \\
plasma stability (human/rat) remaining \% @2 h & $88 \% / 96 \%$ \\
plasma protein binding (human/rat) \% & $>99.9 \% /$ \\
& $>99.9 \%$ \\
bidirectional permeability across Caco-2 cell monolayer (A to & $0.5 / 0.2 / 0.4$ \\
B/B to A/efflux ratio) $10^{-6} \mathrm{~cm} / \mathrm{s}$ & \\
\hline
\end{tabular}

Table 3. In Vitro Safety Profile of Compound 5c

\begin{tabular}{ll}
\multicolumn{1}{c}{ study } & \multicolumn{1}{c}{$\mathrm{IC}_{50}(\mu \mathrm{M})$} \\
CYP1A2/2C9/2C19/2D6/3A4 & $10 / 20 />50 />50 />50$ \\
hERG & $>30$ \\
\hline
\end{tabular}

syndrome. ${ }^{15}$ PPAR $\alpha$ plays a key role not only in lipid metabolism but also in bile acid synthesis and antiinflammatory. The activation of $\operatorname{PPAR} \alpha$ regulates genes responsible for bile formation and transportation, such as CYP7A1 (cytochrome P450 isoform), CYP27A1, UGT1A1, SULT2A1, MDR3, and ASBT. As a result, NF- $\kappa \beta$ (nuclear factor kappa $\beta$ ) could also be inhibited via PPAR $\alpha$ activation, which leads to decreased expression of IL-1 (interleukins) and IL-6. ${ }^{7}$ A few clinical trials explored the effect of PPAR $\alpha$ agonists, fenofibrate, and bezafibrate (Figure 2), in patients with $\mathrm{PBC}$ and demonstrated positive effects. ${ }^{16-22}$ The second subtype is ubiquitously expressed $\operatorname{PPAR} \delta{ }^{23}$ Besides fatty acid catabolism and energy metabolism capacities, the activation of $\operatorname{PPAR} \delta$ decreases cholesterol absorption and synthesis and down-regulates cholesterol $7 \alpha$-hydroxylase, which results in overt anticholestatic activity. ${ }^{24}$ For years, synthetic PPAR $\gamma$ (glitazones) and dual PPAR $\alpha / \gamma$ (glitazars) agonists have been developed to treat dyslipidaemia and T2DM (type 2 diabetes mellitus). ${ }^{25,26}$ Nevertheless, several of them were discontinued because of PPAR $\gamma$ related weight gain, fluid retention, hemodilution, and edema effect on an increasing risk of heart failure in clinical trials. ${ }^{27,28}$ Given the potential pharmacological benefit of activating $\operatorname{PPAR} \alpha / \delta$ in cholestasis and PPAR $\gamma$ related cardiovascular safety concerns, developing a dual $\operatorname{PPAR} \alpha / \delta$ agonist with high selectivity against PPAR $\gamma$ may lead to a better solution in the treatment of PBC.

Results and Discussion. GFT505 (Elafibranor) is a PPARs agonist (Figure 2) for the treatment of $\mathrm{NASH}$ (nonalcoholic steatohepatitis, NCT02704403, phase III) and PBC (NCT03124108, phase II). Preferential activities on $\operatorname{PPAR} \alpha$ and $\delta$ were exhibited for GFT505 with no PPAR $\gamma$ associated adverse cardiac effects; however, it must be used at moderate to high dosage $(80-120 \mathrm{mg} /$ day $)$ to achieve sufficient efficacy. ${ }^{29-32}$ Hence, we describe herein the design and synthesis of novel PPAR $\alpha / \delta$ dual agonists to improve pharmacological activity and selectivity. The rational of drug design for $\operatorname{PPAR} \alpha / \delta$ dual agonist is shown in Figure 3. A

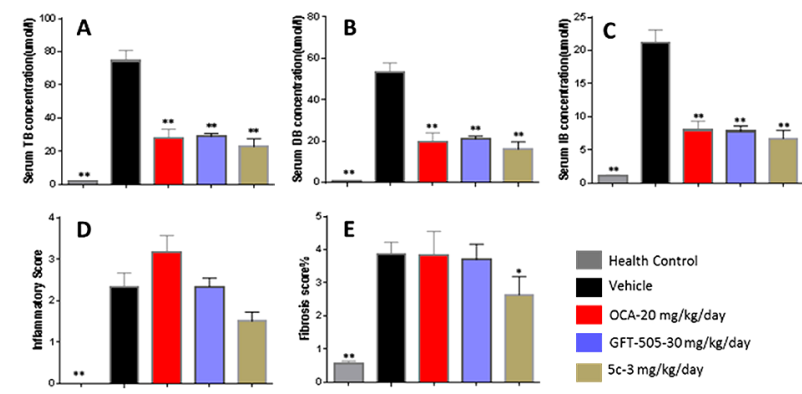

Figure 5. In vivo efficacy study in ANIT supplemented diet induced rat $\mathrm{PBC}$ model. Eight-day $\alpha$-naphthylisothiocyanate supplemented diet provoked rat PBC model. Serum total bilirubin change (A), serum direct/indirect bilirubin change $(B, C)$, inflammatory score change (D), fibrosis score change (E). Data were presented as mean \pm SEM; $* * p<0.01$ vs vehicle group, $* p<0.05$ vs vehicle group, analyzed by unpaired $t$ test.

typical PPARs agonist comprises a carboxylic acid head, a lipophilic tail, and a linker. ${ }^{33-38}$ In a variety of different substructures for head, linker, and tail regions, GFT505 has a remarkable chalcone group, which was assumed to be important. Using GFT505 as a lead compound, $\alpha, \beta$ unsaturated ketone group was replaced with isoxazole linkage. The easily oxidized methylthioyl group was replaced by a more stable bromine atom, which exhibited similar lipophilicity and size. By retaining hydrogen bond interaction and molecular rigidity, and the utilization of a chemical stable substitution, we expect these modifications would improve not only the activity and selectivity of $\operatorname{PPAR} \alpha / \delta$ but also pharmacokinetics properties.

First, compounds with isoxazole linkage were designed and prepared. Reactions of benzaldehydes with hydroxylamine afforded benzaldehyde oximes $\mathbf{2 a - 2 c}$. After the formation of isoxazole analogues by oxidative cyclizations, compounds $\mathbf{5 a -}$ 5d were obtained through simple hydrolysis from ester to acid (Scheme 1). ${ }^{39}$ To switch the fibric acid substitution position on the isoxazole ring, a different pathway was designed for the preparation of compound $\mathbf{1 0}$ (Scheme 2).

The synthesis of polycyclic isoxazole analogues $17 \mathbf{a}$ and $\mathbf{1 7 b}$ was depicted in Scheme 3. $\mathrm{SeO}_{2}$-mediated oxidation transformed 4-hydroxyphenylethanone 12 to 2-oxo-2-phenylacetic acid $13 .^{40,41}$ After the chlorination, the $\alpha$-alkylation of benzoxepin-5-one proceeded, followed by hydroxylamine participated annulations. Deoxydation and subsequent hydrolysis reactions provided compounds $17 \mathbf{a}$ and $17 \mathbf{b}$, ultimately.

The novel isoxazole analogues were evaluated in a nuclear hormone receptor (NHR) assay. ${ }^{42}$ The \% activation of all test compounds was compared to reference compounds that were normalized to $100 \%$. For $\operatorname{PPAR} \alpha, \delta$, and $\gamma$ activities, the reference compounds were GW7647, L-165,041, and troglitazone, respectively. Initially, the structure-activity relationship

Table 4. Pharmacokinetic Parameters of 5c after a Single Intravenous or Oral Dose Administration in Mice and Rats

\begin{tabular}{|c|c|c|c|c|c|c|c|c|c|}
\hline species & route & dose $(\mathrm{mg} / \mathrm{kg})$ & $V_{\mathrm{dss}}(\mathrm{L} / \mathrm{kg})$ & $\mathrm{Cl}(\mathrm{mL} / \mathrm{min} / \mathrm{kg})$ & $T_{1 / 2}(\mathrm{~h})$ & $\mathrm{AUC}_{0 \text {-last }}(\mathrm{nM} \cdot \mathrm{h})$ & $C_{\max }(\mathrm{nM})$ & $T_{\max }(\mathrm{h})$ & $F(\%)$ \\
\hline \multirow[t]{2}{*}{ C57BL/6 mouse } & i.v. $^{a}$ & 1 & 0.53 & 3.53 & 3.6 & 10566 & NA & NA & 59.8 \\
\hline & p.o. ${ }^{b}$ & 10 & NA & NA & NA & 63211 & 52000 & 0.33 & \\
\hline \multirow[t]{2}{*}{ SD rat } & i.v. $^{a}$ & 1 & 0.16 & 0.35 & 6.0 & 105180 & NA & NA & 53.3 \\
\hline & p.o. ${ }^{b}$ & 10 & NA & NA & NA & 561136 & 65267 & 1.33 & \\
\hline
\end{tabular}

${ }^{a}$ Formulation of intravenous dosing was prepared in DMSO $/ 10 \% \mathrm{HP}-\beta-\mathrm{CD}=5: 95(\mathrm{v} / \mathrm{v}) .{ }^{b}$ Oral formulation was prepared in $0.1 \%$ Tween $80 / 1 \%$ CMC-Na in distilled water. 
(SAR) study was set up in $\operatorname{PPAR} \alpha$ assay. Replacing chalcone structure with isoxazole ring led to compound 5a with loss of in vitro activity, while GFT505 showed an $\mathrm{EC}_{50}$ of $225 \mathrm{nM}$ on $\operatorname{PPAR} \alpha$. However, encouraging results were observed when extended carbon chains were employed. Compounds 5c and $\mathbf{5 d}$ are both full agonists, whose potency is 8-28-fold higher than GFT505 (PPAR $\alpha \mathrm{EC}_{50}=8 \mathrm{nM}$ for 5c and $27 \mathrm{nM}$ for 5d). With the introduction of bromine atom, the activity of $5 \mathrm{c}$ was 47-fold higher than $\mathbf{5 b}\left(\operatorname{PPAR} \alpha \mathrm{EC}_{50}=385 \mathrm{nM}\right.$ for $\left.\mathbf{5 b}\right)$. Switching the position of fibric acid led to a remarkable decrease in PPAR $\alpha$ potency (PPAR $\alpha \mathrm{EC}_{50}=2821 \mathrm{nM}$ for 10). As a result, the cyclization of phenyl and isoxazole group, which generated polycyclic isoxazole analogues $17 \mathbf{a}$ and $17 \mathbf{b}$, exhibited no effects on improving activities.

Next, we moved on to the evaluation of the selectivity of PPAR $\alpha$ and $\delta$ against PPAR $\gamma$ (Table 1). PPAR $\alpha / \delta$ dual agonist GFT505 showed good potency for both PPAR $\alpha$ and $\delta$ $\left(\operatorname{PPAR} \alpha \mathrm{EC}_{50}=225 \mathrm{nM}, \operatorname{PPAR} \delta \mathrm{EC}_{50}=115 \mathrm{nM}\right)$, and moderate to high selectivity for PPAR $\gamma / \alpha$ and $\gamma / \delta$ (PPAR $\gamma$ $\left.\mathrm{EC}_{50}=2116 \mathrm{nM}, \gamma / \alpha=9, \gamma / \delta=18\right)$. Interestingly, selected isoxazole analogues $\mathbf{5 c}$ and $\mathbf{5 d}$, which showed higher PPAR $\alpha$ activity than GFT505, indicated excellent in vitro $\mathrm{PPAR} \delta$ potency $\left(\operatorname{PPAR} \delta \mathrm{EC}_{50}=5 \mathrm{nM}\right.$ for $5 \mathrm{c}, \operatorname{PPAR} \delta \mathrm{EC}_{50}=5 \mathrm{nM}$ for 5d). Both of them acted as partial PPAR $\delta$ agonists as GFT505 did. Compound 5c has a $\mathrm{EC}_{50}$ value of PPAR $\gamma$ as $2939 \mathrm{nM}$, which means the higher selectivity for $\operatorname{PPAR} \alpha$ and $\delta(\gamma / \alpha=$ $367, \gamma / \delta=588)$ over PPAR $\gamma$ than that of GFT505. However, an $\mathrm{EC}_{50}=457 \mathrm{nM}$ for PPAR $\gamma$ was noted for $5 \mathbf{d}$ when a dimethylene group was employed. Since PPAR $\gamma$ activity results in a series of cardiovascular safety concerns, compound $\mathbf{5 d}$ was not selected for further investigation. The SAR study of the isoxazole linker group presented that compound 5c was optimal, providing potent PPAR $\alpha / \delta$ activities and the highest level of PPAR $\alpha / \delta$ selectivity against $\operatorname{PPAR} \gamma$.

The structure of PPAR includes a DNA binding domain (DBD) and a ligand binding domain (LBD). The smallmolecule agonists can bind to LBD and stabilize an active conformation form, activating transcription process of the downstream proteins. ${ }^{43-46}$ LBD of PPARs consisted of $12 \alpha$ helixes. The last helix, called AF-2 segment, can help to bind with variant cofactors and therefore is very important for receptor activation. The binding pocket of $\operatorname{PPAR} \alpha$ and PPAR $\delta$ is mainly in "Y" shape that can be divided into three "arms" regions. To better understand the SAR and selectivity profile, these compounds have been modeled in the three PPAR subtypes by molecular docking. PDB codes of the crystal structures used in docking are 4CI4 for $\operatorname{PPAR} \alpha, 1 \mathrm{GWA}$ for $\operatorname{PPAR} \delta$, and $3 \mathrm{VJH}$ for PPAR $\gamma .{ }^{17}$ The detailed interactions of key compounds with proteins are shown in Figure 4.

It can be seen that 5c can take a "U"-shaped conformation and occupy the arm I and arm II regions of PPAR $\alpha$. The carboxylic acid of $\mathbf{5 c}$ binds to arm I region, forming $\mathrm{H}$-bond network to Tyr314, His440, and Tyr464. The dimethyl phenyl has $\pi-\pi$ stacking with Phe318 and His440, meanwhile interacting with hydrophobic residues in arm I subpocket. The isoxazole linker can provide appropriate geometry to place the moieties on both sides in arm I and II, respectively. When the substituent group is moved from position 5 to 4 , the linking angle was changed and significant activity drop $(>300$ folders, 5c versus 10) was observed. Moreover, the isoxazole oxygen can catch an H-bond with Thr279, which is one of the important factors of selectivity against $\operatorname{PPAR} \gamma$. The bromine phenyl can bind to a highly hydrophobic pocket in arm II region. The role of bromine here is to better occupy the binding pocket and form more hydrophobic interactions with protein. Removing bromine will drop activity over 50-fold (5c versus $\mathbf{5 b}$ ). The binding insight of $\mathbf{5} \mathbf{c}$ in PPAR $\delta$ is very close to that in PPAR $\alpha$ (Figure 4a,b).

The binding pocket of PPAR $\gamma$ has less similarity to PPAR $\alpha$ and $\operatorname{PPAR} \delta$. Different residues of the three subtypes around active site are shown in Figure 4c,d. As mentioned above, isoxazole can catch an H-bond interaction to Thr279 in PPAR $\alpha$ and match well to the binding pocket. The residue on the same position of PPAR $\delta$ is Thr252. However, there is a big and polar residue, Arg288, on this position of PPAR $\gamma$. It can be seen that $5 \mathrm{c}$ has good activity on both $\operatorname{PPAR} \alpha$ and $\operatorname{PPAR} \delta$ but has poor activity on PPAR $\gamma$. When the linker is prolonged by one more methylene, the activity of PPAR $\alpha$ is slightly dropped, but the activity on $\operatorname{PPAR} \gamma$ increased over 6-fold (5c versus 5d). This is because the enhanced flexibility can help take a better "U"-shaped conformation, reducing steric repulsion to Arg288.

ADME, PK Results, and Discussion. The most potent and selective compound $\mathbf{5 c}$ had distinguished in vitro $\mathrm{ADME}$ and in vivo $\mathrm{PK}$ profiles. Compound $\mathbf{5 c}$ was stable in human and rat microsome and plasma. However, 5c was a highly plasma protein binding compound, with protein binding above $99.9 \%$ in both human and rat plasma. Compound 5c showed moderate permeability based on the Caco2 assay (Table 2).

Compound 5c indicated no significant inhibition on five human CYP isozymes. An in vitro cardiovascular safety evaluation also exhibited no hERG potassium channel activity at concentrations up to $30 \mu \mathrm{M}$ (Table 3 ).

The pharmacokinetic profile of $\mathbf{5 c}$ is presented in Table 4. Across all tested species, mouse and rat, $\mathbf{5 c}$ showed low plasma clearance. The half-life of $5 \mathrm{c}$ was $3.6 \mathrm{~h}$ in mouse and $6.0 \mathrm{~h}$ in rat. A remarkable high oral plasma exposure of $5 \mathrm{c}$ indicated a significant absolute oral bioavailability, which was $59.8 \%$ in mouse and $53.3 \%$ in rat, respectively.

Pharmacology. Having been identified as a potent and selective dual PPAR $\alpha / \delta$ agonist with favorable PK profile, 5c was further studied in an in vivo efficacy model. A rat model induced by 8 -day ANIT ( $\alpha$-naphthylisothiocyanate) supplemented diet provoked increased TB (total bilirubin) and inflammation parameters. Severe hepatic fibrosis could also be determined in this model. To evaluate the effect on PBC, a comparative study of $5 \mathrm{c}(3 \mathrm{mg} / \mathrm{kg} / \mathrm{day}$, once daily) versus OCA $(20 \mathrm{mg} / \mathrm{kg} /$ day, once daily) and GFT505 $(30 \mathrm{mg} / \mathrm{kg} /$ day, once daily) was performed in this experiment (six animals per group). By comparison with OCA $-20 \mathrm{mg} / \mathrm{kg} /$ day and GFT $505-30 \mathrm{mg} / \mathrm{kg} /$ day, compound $5 \mathrm{c}$ indicated obvious TB (including DB-direct bilirubin and IB-indirect bilirubin) lowering effect at only $3 \mathrm{mg} / \mathrm{kg} /$ day (Figure $5 \mathrm{~A}-\mathrm{C}$ ). Furthermore, 5c lowered inflammatory score by $30 \%$ (from 2.3 to 1.6$)$ and reduced fibrosis area percentage by $28 \%(3.9 \%$ to $2.8 \%$ ). No obvious change was observed for inflammatory score and fibrosis when GFT505-30 mg/kg/day and OCA-20 $\mathrm{mg} / \mathrm{kg} /$ day were utilized. This was probably due to the lower dosage of OCA in the study and poorer in vitro potency of GFT505, respectively. In the meantime, the FXR potency of 5c was checked in a FXR binding assay to exclude the combinational efficacy of FXR agonism in the PBC model. Its $\mathrm{IC}_{50}$ for $\mathrm{FXR}$ of $\mathbf{5 c}$ was more than $50 \mu \mathrm{M}$, and the selectivity against $\operatorname{PPAR} \alpha$ and $\delta$ is over 6000 .

Conclusion. In summary, we described the development of novel PPAR $\alpha / \delta$ dual agonists. Compound 5c was found to be 
the most potent and highly selective PPAR $\alpha / \delta$ agonist (PPAR $\alpha / \delta / \gamma, \mathrm{EC}_{50}=8 / 5 / 2939 \mathrm{nM}, \mathrm{EC}_{50} \gamma / \alpha$ ratio $=367, \mathrm{EC}_{50} \gamma / \delta$ ratio $=588, \mathrm{FXR} / \mathrm{PPAR}>6000)$. With good ADME profile, 5c exhibited excellent in vivo efficacy in a rat $\mathrm{PBC}$ model. On the basis of pharmacological effects described above, compound 5c was identified as a promising lead compound for further optimization.

\section{ASSOCIATED CONTENT}

\section{S Supporting Information}

The Supporting Information is available free of charge on the ACS Publications website at DOI: 10.1021/acsmedchemlett.9b00189.

Synthetic procedures, analytical data, and assay protocol (PDF)

\section{AUTHOR INFORMATION}

\section{Corresponding Authors}

*E-mail: he_haiying@wuxiapptec.com.

*E-mail: chenzhenyu2000@zspcl.com.

\section{ORCID}

Zhigan Jiang: 0000-0001-7277-330X

\section{Notes}

The authors declare no competing financial interest.

\section{ACKNOWLEDGMENTS}

The work financially supported by National Major Scientific and Technological Special Project for "Significant New Drugs Development” (No. 2018ZX09201001-002-001).

\section{ABBREVIATIONS}

PK, pharmacokinetics; PO, per os; $C_{\max }$ peak concentration; $T_{\max }$ time to peak; CL, clearance; $T_{1 / 2}$, half-life; $V_{\mathrm{d}}$, volume of distribution; AUC, area under curve; $\mathrm{mpk}, \mathrm{mg} / \mathrm{kg}$; $\% \mathrm{~F}$, oral bioavailability

\section{REFERENCES}

(1) Talwalkar, J. A.; Lindor, K. D. Primary biliary cirrhosis. Lancet 2003, 9377, 53-61.

(2) Kaplan, M. M.; Gershwin, M. E. Primary biliary cirrhosis. N. Engl. J. Med. 2005, 353, 1261-1273.

(3) Ikegami, T.; Matsuzaki, Y. Ursodeoxycholic acid: mechanism of action and novel clinical applications. Hepatol. Res. 2007, 38, 123131.

(4) Lindor, K. D.; Gershwin, M. E.; Poupon, R.; Kaplan, M.; Bergasa, N. V.; Heathcote, E. J. Primary biliary cirrhosis. Hepatology 2009, 50, 291-308.

(5) Raoul, P.; YVES, C.; Yvon, C. Is Ursodeoxycholic Acid an Effective Treatment for Primary Biliary Cirrhosis? Lancet 1987, 11, 834-836.

(6) Angulo, P.; Batts, K. P.; Therneau, T. M.; Jorgensen, R. A.; Dickson, E. R.; Lindor, K. D. Long-Term Ursodeoxycholic Acid Delays Histological Progression in Primary Biliary Cirrhosis. Hepatology 1988, 29 (3), 644-647.

(7) Corpechot, C.; Carrat, F.; Bonnand, A.-M.; Poupon, R. E.; Poupon, R. The Effect of Ursodeoxycholic Acid Therapy on Liver Fibrosis Progression in Primary Biliary Cirrhosis. Hepatology 2000, 32 (6), 1196-1199.

(8) Lindor, K. D.; Jorgensen, R. A.; Therneaus, T. M.; Malinchoc, M.; Dickson, E. R. Ursodeoxycholic acid delays the onset of esophageal varices in primary biliary cirrhosis. Mayo. Clin. Proc. 1997, 72, 1137-1140.

(9) Poupon, R. E.; Lindor, K. D.; Cauch-Dudek, K.; Dickson, E. R.; Poupon, R.; Heathcote, E. J. Combined analysis of randomized controlled trials of ursodeoxycholic acid in primary biliary cirrhosis. Gastroenterology 1997, 113, 884-890.

(10) Usual adult dose of obeticholic acid for biliary cirrhosis: (1) initial dose, $5 \mathrm{mg}$ orally once a day. (2) Maintenance dose: $5 \mathrm{mg}$ orally once a day. (3) If adequate reduction in ALP (alkaline phosphatas) and/or total bilirubin is not achieved after 3 months, increase the dosage to $10 \mathrm{mg}$ orally once a day. (4) Maximum dose: $10 \mathrm{mg} /$ day.

(11) Pellicciari; et al. The Discovery of Obeticholic acid (Ocaliva): First-in-Class FXR Agonist-Successful Drug Discovery; Wiley, 2018; Vol. 3.

(12) Pares, A.; Caballeria, L.; Rodes, J. Excellent long-term survival in patients with primary biliary cirrhosis and biochemical response to ursodeoxycholic acid. Gastroenterology 2006, 130, 715-720.

(13) The Food and Drug Administration (FDA) warned that OCA was being incorrectly dosed in some patients with moderate to severe decreases in liver function in September 21st, 2017. These patients were receiving excessive dosing, particularly a higher frequency of dosing than was recommended in the drug label, which would result in an increased risk of serious liver injury and death. OCA may also be associated with liver injury in some patients with mild disease who are receiving the correct dose.

(14) Ghonem, N. S.; Assis, D. N.; Boyer, J. L. On fibrates and cholestasis: a review. Hepatology 2015, 62, 635-643.

(15) Polvani, S.; Tarocchi, M.; Tempesti, S.; Bencini, L.; Galli, A. Peroxisome proliferator activated receptors at the crossroad of obesity, diabetes, and pancreatic cancer. World J. Gastroenterol. 2016, 22, 2441-2459.

(16) Hazzan, R.; Tur-Kaspa, R. Bezafibrate treatment of primary biliary cirrhosis following incomplete response to ursodeoxycholic acid. J. Clin. Gastroenterol. 2015, 44, 371-373.

(17) Ohira, H.; Sato, Y.; Ueno, T.; Sata, M. Fenofibrate treatment in patients with primary biliary cirrhosis. Am. J. Gastroenterol. 2002, 97, 2147-2149.

(18) Iwasaki, S.; Ohira, H.; Nishiguchi, S.; Zeniya, M.; Kaneko, S.; Onji, M.; Ishibashi, H.; Sakaida, I.; Kuriyama, S.; Ichida, T.; Onishi, S.; Toda, G. The efficacy of ursodeoxycholic acid and bezafibrate combination therapy for primary biliary cirrhosis: a prospective, multicenter study. Hepatol. Res. 2008, 38, 557-564.

(19) Kanda, T.; Yokosuka, O.; Imazeki, F.; Saisho, H. Bezafibrate treatment: a new medical approach for PBC patients? J. Gastroenterol. 2003, 38, 573-578.

(20) Dohmen, K.; Mizuta, T.; Nakamuta, M.; Shimohashi, N.; Ishibashi, H.; Yamamoto, K. Fenofibrate for patients with asymptomatic primary biliary cirrhosis. World J. Gastroenterol. 2004, $10,894-898$

(21) Itakura, J.; Izumi, N.; Nishimura, Y.; Inoue, K.; Ueda, K.; Nakanishi, H.; Tsuchiya, K.; Hamano, K.; Asahina, Y.; Kurosaki, M.; Uchihara, M.; Miyake, S. Prospective randomized crossover trial of combination therapy with bezafibrate and UDCA for primary biliary cirrhosis. Hepatol. Res. 2004, 29, 216-222.

(22) Levy, C.; Peter, J. A.; Nelson, D. R.; Keach, J.; Petz, J.; Cabrera, R.; Clark, V.; Firpi, R. J.; Morelli, G.; Soldevila-Pico, C.; Lindor, K. Pilot study: fenofibrate for patients with primary biliary cirrhosis and an incomplete response to ursodeoxycholic acid. Aliment. Pharmacol. Ther. 2011, 33, 235-242.

(23) Luquet, S.; Gaudel, C.; Holst, D.; Lopez-Soriano, J.; Jehl-Pietri, C.; Fredenrich, A.; Grimaldi, P. A. Roles of PPAR $\delta$ in lipid absorption and metabolism: a new target for the treatment of type 2 diabetes. Biochim. Biophys. Acta, Mol. Basis Dis. 2005, 1740, 313-317.

(24) Jones, D.; Boudes, P. F.; Swain, M. G.; Bowlus, C. L.; Galambos, M. R.; Bacon, B. R.; Doerffel, Y.; Gitlin, N.; Gordon, S. C.; Odin, J. A.; Sheridan, D.; Wörns, M. A.; Clark, V.; Corless, L.; Hartmann, H.; Jonas, M. E.; Kremer, A. E.; Mells, G. F.; Buggisch, P.; Freilich, B. L.; Levy, C.; Vierling, J. M.; Bernstein, D. E.; Hartleb, M.; Janczewska, E.; Rochling, F.; Shah, H.; Shiffman, M. L.; Smith, J. H.; Choi, Y. J.; Steinberg, A.; Varga, M.; Chera, H.; Martin, R.; McWherter, C. A.; Hirschfield, G. M. Seladelpar (MBX-8025), a selective PPAR- $\delta$ agonist, in patients with primary biliary cholangitis 
with an inadequate response to ursodeoxycholic acid: a double-blind, randomised, placebo-controlled, phase 2, proof-of-concept study. Lancet Gastroenterol. Hepatol. 2017, 2, 716-726.

(25) Lecka-Czernik, B. Aleglitazar, a dual PPARalpha and PPARgamma agonist for the potential oral treatment of type 2 diabetes mellitus. IDrugs 2010, 13, 793-801.

(26) Nissen, S. E.; Wolski, K.; Topol, E. J. Effect of muraglitazar on death and major adverse cardiovascular events in patients with type 2 diabetes mellitus. JAMA 2005, 294, 2581-2586.

(27) Cariou, B.; Charbonnel, B.; Staels, B. Thiazolidinediones and PPARgamma agonists: time for a reassessment. Trends Endocrinol. Metab. 2012, 23, 205-215.

(28) Lincoff, A. M.; Tardif, J. C.; Schwartz, G. G.; Nicholls, S. J.; Rydén, L.; Neal, B.; Malmberg, K.; Wedel, H.; Buse, J. B.; Henry, R. R.; Weichert, A.; Cannata, R.; Svensson, A.; Volz, D.; Grobbee, D. E. Effect of aleglitazar on cardiovascular outcomes after acute coronary syndrome in patients with type 2 diabetes mellitus: the AleCardio randomized clinical trial. JAMA 2014, 311, 1515-1525.

(29) Cariou, B.; Zair, Y.; Staels, B.; Bruckert, E. Effects of the new dual PPAR alpha/delta agonist GFT505 on lipid and glucosehomeostasis in abdominally obese patients with combined dyslipidemia or impaired glucose metabolism. Diabetes Care 2011, 34, 2008-2014.

(30) Cariou, B.; Hanf, R.; Lambert-Porcheron, S.; Zaï, Y.; Sauvinet, V.; Noël, B.; Flet, L.; Vidal, H.; Staels, B.; Laville, M. Dual peroxisome proliferator-activated receptor alpha/delta agonist GFT505 improves hepatic and peripheral insulin sensitivity in abdominally obese subjects. Diabetes Care 2013, 36, 2923-2930.

(31) Staels, B.; Rubenstrunk, A.; Noel, B.; Rigou, G.; Delataille, P.; Millatt, L. J.; Baron, M.; Lucas, A.; Tailleux, A.; Hum, D. W.; Ratziu, V.; Cariou, B.; Hanf, R. Hepatoprotective effects of the dual peroxisome proliferator-activated receptor alpha/delta agonist, GFT505, in rodent models of nonalcoholic fatty liver disease/ nonalcoholic steatohepatitis. Hepatology 2013, 58, 1941-1952.

(32) Hanf, R.; Millatt, L.; Cariou, B.; Noel, B.; Rigou, G.; Delataille, P.; Daix, V.; Hum, D.; Staels, B. The dual peroxisome proliferatoractivated receptor alpha/delta agonist GFT505 exerts anti-diabetic effects in $\mathrm{db} / \mathrm{db}$ mice without peroxisome proliferator-activated receptor gamma-associated adverse cardiac effects. Diabetes Vasc. Dis. Res. 2014, 11, 440-447.

(33) Nomura, M.; Kinoshita, S.; Satoh, H.; Maeda, T.; Murakami, K.; Tsunoda, M.; Miyachi, H.; Awano, K. (3-Substituted benzyl)thiazolidine-2,4-diones as structurally new antihyperglycemic agents. Bioorg. Med. Chem. Lett. 1999, 9, 533-538.

(34) Murakami, K.; Tobe, K.; Ide, T.; Mochizuki, T.; Ohashi, M.; Akanuma, Y.; Yazaki, Y.; Kadowaki, T. A novel insulin sensitizer acts as a coligand for peroxisome proliferator-activated receptor-alpha (PPAR-alpha) and PPAR-gamma: effect of PPAR-alpha activation on abnormal lipid metabolism in liver of Zucker fatty rats. Diabetes 1998, 47, 1841-1847.

(35) Devasthale, P. V.; Chen, S.; Jeon, Y.; Qu, F.; Shao, C.; Wang, W.; Zhang, H.; Cap, M.; Farrelly, D.; Golla, R.; Grover, G.; Harrity, T.; Ma, Z.; Moore, L.; Ren, J.; Seethala, R.; Cheng, L.; Sleph, P.; Sun, W.; Tieman, A.; Wetterau, J. R.; Doweyko, A.; Chandrasena, G.; Chang, S. Y.; Humphreys, W. G.; Sasseville, V. G.; Biller, S. A.; Ryono, D. E.; Selan, F.; Hariharan, N.; Cheng, P. T. Design and Synthesis of $\mathrm{N}$-[(4-Methoxyphenoxy) carbonyl]-N-[[4-[2-(5- methyl-2-phenyl-4oxazolyl) ethoxy] phenyl] methyl] glycine [Muraglitazar/BMS298585], a Novel Peroxisome Proliferator-Activated Receptor $\alpha / \gamma$ Dual Agonist with Efficacious Glucose and Lipid-Lowering Activities. J. Med. Chem. 2005, 48, 2248-2250.

(36) Cronet, P.; Petersen, J. F.; Folmer, R.; Blomberg, N.; Sjölom, K.; Karlsson, U.; Lindstedt, E. L.; Bamberg, K. Structure of the PPARalpha and -gamma ligand binding domain in complex with AZ 242; ligand selectivity and agonist activation in the PPAR family. Structure 2001, 9, 699-706.

(37) Martín, J. A.; Brooks, D. A.; Prieto, L.; González, R.; Torrado, A.; Rojo, I.; López deUralde, B.; Lamas, C.; Ferritto, R.; Dolores Martín-Ortega, M.; Agejas, J.; Parra, F.; Rizzo, J. R.; Rhodes, G. A.; Robey, R. L.; Alt, C. A.; Wendel, S. R.; Zhang, T. Y.; Reifel-Miller, A.;
Montrose-Rafizadeh, C.; Brozinick, J. T.; Hawkins, E.; Misener, E. A.; Briere, D. A.; Ardecky, R.; Fraser, J. D.; Warshawsky, A. M. 2Alkoxydihydrocinnamates as PPAR agonists. Activity modulation by the incorporation of phenoxy substituents. Bioorg. Med. Chem. Lett. 2005, 15, 51-55.

(38) Sauerberg, P.; Pettersson, I.; Jeppesen, L.; Bury, P. S.; Mogensen, J. P.; Wasserman, K.; Brand, C. L.; Sturis, J.; Wödike, H. F.; Fleckner, J.; Andersen, A. S.; Mortensen, S. B.; Svensson, L. A.; Rasmussen, H. B.; Lehman, S. V.; Polivka, Z.; Sindelar, K.; Panajotova, V.; Ynddal, L.; Wulff, E. M. J. Novel Tricyclic- $\alpha$ alkyloxyphenylpropionic Acids: Dual PPAR $\alpha / \gamma$ Agonists with Hypolipidemic and Antidiabetic Activity. J. Med. Chem. 2002, 45, 789-804.

(39) In the protein interaction assay, the PPAR ligand complexes with a PPAR ligand binding domain fused to an inactive fragment of galactosidase. This complex complements another inactive galactosidase fragment to form an active galactosidase enzyme that is read out in a fluorescence assay. For details, please see www.discoverx.com.

(40) Mokale, S. N.; Dube, P. N.; Nevase, M. C.; Sakle, N. S.; Shelke, V. R.; Bhavale, S. A.; Begum, A. Synthesis of some novel substituted phenylisoxazol phenoxy 2-methylpropanoic acids and there in vivo hypolipidemic activity. Medicinal Chemistry Research 2016, 25 (3), 422-428.

(41) EP1657235, 2006.

(42) Xie, J.; Seto, C. T. Investigations of linker structure on the potency of a series of bidentate protein tyrosine phosphatase inhibitors. Bioorg. Med. Chem. 2005, 13 (8), 2981-2991.

(43) Wu, C. C.; Baiga, T. J.; Downes, M.; La Clair, J. J.; Atkins, A. R.; Richard, S. B.; Fan, W. W.; Stockley-Noel, T. A.; Bowman, M. E.; Noel, J. P.; Evans, R. M. Structure basis for specific ligation of the peroxisome proliferator-activated receptor $\delta$. Proc. Natl. Acad. Sci. U. S. A. 2017, 114, E2563-E2570.

(44) Dos Santos, J. C.; Bernardes, A.; Giampietro, L.; Ammazzalorso, A.; De Filippis, B.; Amoroso, R.; Polikarpov, I. Different binding and recognition modes of GL479, a dual agonist of Peroxisome Proliferator-Activated Receptor $\alpha / \gamma$. J. Struct. Biol. 2015, 191, 332-340.

(45) Xu, H. E.; Lambert, M. H.; Montana, V. G.; Parks, D. J.; Blanchard, S. G.; Brown, P. J.; Sternbach, D. D.; Lehmann, J. M.; Wisely, G. B.; Willson, T. M.; Kliewer, S. A.; Milburn, M. V. Molecular recognition of fatty acids by peroxisome proliferatoractivated receptors. Mol. Cell 1999, 3, 397-403.

(46) Kuwabara, N.; Oyama, T.; Tomioka, D.; Ohashi, M.; Yanagisawa, J.; Shimizu, T.; Miyachi, H. Peroxisome proliferatoractivated receptors (PPARs) have multiple binding points that accommodate ligands in various conformations: phenylpropanoic acid-type PPAR ligands bind to PPAR in different conformations, depending on the subtype. J. Med. Chem. 2012, 55, 893-902. 